\title{
Relationship between very low birth weight, environmental factors, and motor and cognitive development of children of 5 and 6 years old
}

\author{
Relação entre muito baixo peso ao nascimento, fatores ambientais e o \\ desenvolvimento motor e o cognitivo de crianças aos 5 e 6 anos
}

Gisele E. Oliveira', Lívia C. Magalhães', Luci F. T. Salmela²

\begin{abstract}
Objective: To examine the relationships between birth weight, preterm birth, environmental factors and the motor and cognitive development of 5 to 6 year-old children. Methods: A case control study in which the motor and cognitive performance, as well as the home environment of children aged 5-6 years, born pre-term and weighing $\leq 1.500$ grams, were compared to peers born full-term and with normal weight. The following testes were used: Movement Assessment Battery for Children (MABC), the Developmental Coordination Disorder Questionnaire (DCDQ), the vocabulary and cube tests of the Weschsler Intelligence Test for Children-III (WISC), the Swanson, Nolan and Pelham IV Scale (SNAP IV) and the Home Observation for Measurement of the Environment (HOME). Results: $50.54 \%$ of the very low birth weight (VLBW) children died and $15.2 \%$ of them demonstrated severe impairments. The scores ( \pm SD) of the VLBW and normal birth weight (NBW) groups were: HOME 33.83 \pm 7.81 (VLBW), 39.61 \pm 8.75 (NBW); MABC 8.17 $\pm 7,10$ (VLBW), 3.06 \pm 3.80 (NBW); DCDQ 54.0 \pm 11.3 (VLBW), 63.0 \pm 7.5 (NBW); WISC Cubes 8.35 \pm 2.15 (VLBW), 10.57 \pm 2.25 (NBW); WISC Vocabulary 9.61 \pm 2.62 (VLBW), $13.48 \pm 2.45$ (NBW); SNAP IV 4.04 \pm 4.95 (VLBW), 1.57 \pm 3.27 (NBW). Significant differences between the groups were found, with higher scores on all measures for the NBW group. The results of the motor and cognitive tests demonstrated correlations with birth weight $(p<0.01)$ and HOME scores $(p<0.05)$. Conclusions: The findings reaffirmed the evidences that children born pre-term and with VLBW were more vulnerable to have motor and cognitive impairments, compared to those born full-term. Environmental factors appeared to interfere with development of these children.
\end{abstract}

Keywords: low birth weight; child development; motor skills; cognition; social conditions.

\section{Resumo}

Objetivo: Examinar as relações entre baixo peso ao nascimento, prematuridade, fatores ambientais e os desenvolvimentos motor e cognitivo de crianças aos 5 e 6 anos de idade. Métodos: Estudo caso-controle no qual os desempenhos motor e cognitivo e o ambiente domiciliar de crianças com idade de 5-6 anos, nascidas pré-termo e com peso $\leq 1.500$ gramas, foram comparados com os de pares nascidos a termo e com peso adequado (PA). Foram utilizados os testes Movement Assessment Battery for Children (MABC), Developmental Coordination Disorder Questionnaire (DCDQ), as provas de vocabulário e de cubos do Weschsler Intelligence Test for Children-III (WISC), o Swanson, Nolan and Pelham IV Scale (SNAP IV) e o Observation for Measurement of the Environment (HOME). Resultados: 50,54\% das crianças nascidas com muito baixo peso (MBP) foram a óbito, e 15,2\% deste grupo desenvolveram sequelas severas. Os escores para os grupos de MBP e de PA foram: HOME 33,83 $\pm 7,81(\mathrm{MBP}), 39,61 \pm 8,75(\mathrm{PA})$; MABC 8,17 $\pm 7,10$ (MBP), 3,06 $\pm 3,80$ (PA); DCDQ 54,0 $\pm 11,3$ (MBP), 63,0 $\pm 7,5(P A)$; WISC Cubos 8,35 $\pm 2,15(\mathrm{MBP}), 10,57 \pm 2,25$ (PA); WISC

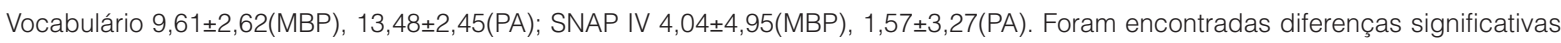
entre os grupos, com melhor desempenho em todos os testes no grupo de PA. Os resultados dos testes motores e cognitivos tiveram correlação com o peso ao nascer $(p<0,01)$ e com o HOME $(p<0,05)$. Conclusões: Os resultados reforçaram as evidências de que crianças nascidas prematuras e de MBP são mais propensas a apresentar dificuldades motoras e cognitivas que seus pares nascidos a termo e de PA. Fatores ambientais parecem interferir no desenvolvimento dessas crianças.

Palavras-chave: recém-nascido de baixo peso; desenvolvimento infantil; desenvolvimento motor; cognição; condições sociais.

Received: 11/04/2010 - Revised: 08/10/2010 - Accepted: 08/02/2011

${ }^{1}$ Department of Occupational Therapy, School of Physical Education, Physical Therapy and Occupational Therapy, Universidade Federal de Minas Gerais (UFMG), Belo Horizonte, MG, Brazil ${ }^{2}$ Physical Therapy Department, School of Physical Education, Physical Therapy and Occupational Therapy, UFMG

Correspondence to: Gisele Eleutério de Oliveira. Rua Salinas, N 1051, Bairro Sidil, CEP 35500-020, Divinópolis, MG, Brasil, e-mail: giseleeleuterio@yahoo.com.br 


\section{Introduction $: \because$.}

The Information System of Live Births of the Ministry of Health/DATASUS-Brazil indicates the increasing survival of children born preterm with very low birth weight (VLBW). In the Brazilian state of Minas Gerais, in 2005, from 277,468 live births, 19,354 were pre-term and 3,676 with birth weight $\leq 1.499$ grams. It is estimated, in that population, a prevalence from 7 to $20 \%$ of severe neurological disorders, such as cerebral palsy and sensory disabilities, and from 30 to $40 \%$ of moderate to mild motor problems will occur ${ }^{1}$. With the improvement in life expectancy of these children, the risk for developmental disabilities has become a growing focus for research and intervention, with a move from the quantitative interest related to survival, to a more qualitative interest, in regards to the consequences of prematurity and low birth weight in the child's development ${ }^{2}$.

There is evidence that, when compared with their peers, these children exhibit difficulties in several areas of development, including problems with motor coordination, attention, academic performance and behavior ${ }^{3}$. Despite the relevance of biological risk factors, environmental conditions also act in a decisive manner and may aggravate or mitigate the impact of biological risk in the child development ${ }^{1}$. Several national studies $^{4-8}$ have focused on motor, cognitive and behavioral aspects of children born preterm and with low birth weight, however, the association with environmental factors is hardly examined, while, paradoxically, the impact of environmental risk in the development may be greater in developing countries $^{9}$, since more children are exposed to impoverished environments.

Considering the importance of examining the relationship between biological and environmental risk factors, this study aimed to describe the motor and cognitive development of a group of children with birth weight $\leq 1,500$ grams, in 2001 and 2002, in the city of Divinópolis, MG, Brazil, and to examine the relationship between VLBW, environmental factors and the motor and cognitive development of 5 to 6 year-old children.

\section{Methods $: \therefore$.}

This is a case control study, which the target population consisted of 5990 live births from Divinópolis, MG, Brazil, born between 2001 and 2002. Upon approval of the Municipal Department of Health of Divinópolis, screening was performed in the Live Birth Certificates data. Children with birth weight $\leq 1,500$ grams were identified and the data were compared with the death certificates. Then, contact was made with families, by phone or home visit, for location of survivors that met the following inclusion criteria: absence of neurological and/or orthopedic problems, malformations, genetic syndromes, sensory deficits or other evident disabilities. These children constituted the group of preterm infants with VLBW, which was matched, by age and social level, with full-term infants with birth weight $\geq 2,500$ grams, which constituted the group with normal birth weight (NBW). For matching for age, a variability of up to 30 days was allowed. To try to maintain equivalence of social level, the children were matched according to the school attended (public or private) and it was also applied a sociodemographic questionnaire to help the comparison of the groups.

After signing the consent form, the home visit was scheduled. Children from both groups were assessed in their own home by a single examiner with extensive experience in the field of child development.

Motor function was assessed using the Developmental Coordination Disorder Questionnaire - Brazilian version (DCDQ-Brazil) ${ }^{10}$, a parent questionnaire specific for screening for Developmental Coordination Disorder (DCD). The DCDQ assess the performance of children in situations of daily life, and the items are rated on a five point scale: the higher the score, the better the motor performance of children. The Movement Assessment Battery for Children (MABC) $)^{11}$ was also used, a motor coordination test, widely used for identification of DCD. The MABC assess manual dexterity, static and dynamic balance and ball skills. Each item is scored from zero to five and, the higher the score, the worse the motor performance. The total score is converted into a percentile. Both DCDQ-Brazil and the MABC adopt the 5th percentile as a cutoff point for identification of DCD.

Cognitive function was assessed with the Weschsler Intelligence Test for Children III (WISC III) ${ }^{12}$, traditional test of intelligence, translated and standardized for the Brazilian children. The cubes and vocabulary tests were utilized, as they show good correlation with the total score ${ }^{13}$.

With the authorization of the Local Department of Education and after signing an informed consent, the children's teachers answered to the Swanson, Nolan and Pelham IV Scale $(\text { SNAP-IV })^{14,15}$, questionnaire adapted into Portuguese ${ }^{15}$ and used to screen for Attention Deficit Hyperactivity Disorder (ADHD) in schoolchildren. The SNAP-IV is interpreted according to the score achieved on the criteria for ADHD and the higher the score, the worse the performance. The home environment was assessed by the Home Observation for Measurement of the Environment (HOME) ${ }^{16}$, observational inventory for systematic assessment of the quality and quantity of stimuli available in the home environment. Higher scores indicate more enriched environments and more suitable for child development. The HOME includes a questionnaire with 
sociodemographic data of the family, which were used for comparison between groups.

In addition to standardized instruments, two protocols for data collection were developed: (a) structured interview with parents about important aspects of child development and (b) a questionnaire for teachers about the children's school performance.

Before data collection, the examiner was trained in the use of the tests and the reliability with another examiner was verified. The intraclass correlation coefficient (ICC), with absolute agreement and confidence interval of $95 \%$ was used to verify inter-rater reliability, obtaining an $\mathrm{ICC}_{3,2}$ of 0.99 for HOME, MABC and WISC-III tests.

For data analysis, the Statistical Package for the Social Sciences - SPSS (version 13.0) was used. Descriptive statistics with measures of mean, standard deviation and median was used to describe the sample. Variables were examined for normal distribution using the Shapiro Wilk test. As normality was not confirmed for most variables, the nonparametric Mann-Whitney test was used to compare the performance of both groups on the tests. The association between the two groups, and the variables income salary, mother's and father's level of education were assessed using the chi-square test.

Finally, the nonparametric correlation coefficient of Spearman was calculated to examine the strength of association between the total scores of the tests and the following quantitative variables: birth weight, income salary, mother's and father's level of education. For all analysis, a significance level $\alpha<0.05$ was considered.
This study was approved by the Committee of Ethics in Research of the Universidade Federal de Minas Gerais (COEP/ UFMG), Belo Horizonte, MG, Brazil, №. ETIC 332/07.

\section{Results : : :}

From a total of 5,990 children, 93 were born with birth weight $\leq 1,500$ grams. Among these 93 children, 47 have died, 13 were not located, three refused to participate in the study and seven were excluded; lasting 23 for the study, being 14 females and nine males. Of the seven excluded children, five had cerebral palsy and two had sensory impairments.

The sample description is summarized in Table 1. In relation to global development, as reported by the mothers, $43.5 \%$ of children in VLBW group had motor and/or language delay, and $60.9 \%$ were referred to stimulation programs in the first year of life. In the NBW group, there were reports of motor delay of only one child (4.3\%). In the VLBW group, 30.4\% of mothers reported perceiving differences between the current development of their child and other children with the same age; while in the NBW group, only one mother (4.3\%) had the same perception. Except for one child in the VLBW group who did not attend school, the others were attending regular schools, and teachers of $60.8 \%$ of the children in the VLBW group and one (4.3\%) in NBW group reported concerns about children's school performance.

Although it is possible to identify small differences in family characteristics, the chi-square test indicated no significant differences between groups in the income salary $(\mathrm{p}=1.00)$, mother's level of education ( $\mathrm{p}=0.17$ ) and father's level of education $(\mathrm{p}=0.81)$ variables.

Table 1. Participants' characteristics (mean \pm sd, median, and range [min-max]) of the descriptive variables for the very low birth weight $(n=23)$ and the normal body weight ( $\mathrm{n}=23)$ Groups.

\begin{tabular}{lcccc}
\hline Variable & Group & Mean \pm SD & Median & Range (min-max) \\
\hline \multirow{2}{*}{ Age (months) } & VLBW & $69.39 \pm 7.37$ & 69 & $60-81$ \\
\cline { 2 - 5 } & NBW & $70.30 \pm 7.28$ & 70 & $60-81$ \\
\hline \multirow{2}{*}{$\begin{array}{l}\text { Gestational age } \\
\text { (Weeks) }\end{array}$} & VLBW & $30.04 \pm 2.18$ & 29 & $27-34$ \\
\hline \multirow{2}{*}{ Birth weight (grams) } & NBW & $38.91 \pm 0.42$ & 39 & $38-40$ \\
\hline \multirow{2}{*}{ Apgar (scores) } & VLBW & $1,201.30 \pm 177.51$ & 1,180 & $930-1,500$ \\
\cline { 2 - 5 } & NBW & $3,273.48 \pm 348.53$ & 3,265 & $2,670-3,840$ \\
\hline \multirow{2}{*}{ Hospitalization (days) } & VLBW & $6.83 \pm 2.87$ & 8 & $1-10$ \\
\cline { 2 - 5 } & NBW & $8.91 \pm 0.79$ & 9 & $7-10$ \\
\hline
\end{tabular}

VLBW = very low body weight; NBW = normal body weight. 
The scores of each group and results of the Mann-Whitney test for the HOME Inventory are shown in Table 2. Significant differences were observed, with a higher score for the NBW group in the HOME total score and in the subscales learning material, language stimulation and modeling.

Table 3 shows the results of each group in the motor tests MABC and DCDQ, in cubes and vocabulary subtests of the WISC-III and in the SNAP-IV. There were significant differences in performance between groups in all tests, with better results for the NBW group, except in areas of manual dexterity and balance of the MABC, and of the SNAP-IV in the total score and items related to hyperactivity. With regards to the cutoff point for motor tests, in DCDQ-Brazil, which reflects the views of parents, $21.7 \%$ of the VLBW group showed results suggestive of difficulties with motor coordination in contrast to only $4.3 \%$ in NBW group. In the MABC, $8.7 \%$ of children from the VLBW group showed performance below the fifth percentile, which indicates definite problem of motor coordination, and $21.7 \%$ scored below the 15th percentile, which is considered "suspicious" motor performance. In the NBW group, only one child (4.3\%) had the "suspicious" score.

Table 4 shows the results of the Spearman correlation between the total score in MABC, DCDQ, HOME, WISC Cubes and Vocabulary and SNAP-IV tests with the variables birth weight, income salary, mother's level of education and father's level of education.

\section{Discussion $: \because$.}

The results of the present study showed that a considerable number of children with birth weight $\leq 1,500$ grams have died, and that, among the survivors who were located, $15.2 \%$ developed severe sequelae. Furthermore, among children who had no major sequelae, there was a higher frequency of motor coordination and attention problems. These results are consistent with national and international studies that show worse motor and cognitive performance in children born preterm and with low birth weight ${ }^{17-21}$. The mortality rate was $50.54 \%$. According to SINASC/DATASUS, in Minas Gerais State, Brazil, in the same period, the mortality rate for children with birth weight $\leq 1,499$ grams was 34.64\%. Méio, Lopes and Morsch ${ }^{17}$ showed a rate of $35.38 \%$ of mortality among children born with birth weight $\leq 1,500$ grams. The highest rate of mortality observed in this study suggests that, in small and medium size cities, the survival of VLBW preterm children is still a challenge.

Table 2. Descriptive statistics (mean \pm sd, median, and range [min-max] of the sub-scale and total scores of the home observation for measure of the environment (HOME) for the very low birth weight ( $n=23$ ) and the normal body weight ( $n=23)$ Groups.

\begin{tabular}{|c|c|c|c|c|c|c|}
\hline Variable & Group & Mean \pm SD & Median & $\begin{array}{l}\text { Range } \\
\text { (min-máx) }\end{array}$ & Mann-Whitney U & $p$ value \\
\hline \multirow{2}{*}{ Learning material } & VLBW & $4.57 \pm 3.10$ & 4 & $0-11$ & \multirow{2}{*}{168.5} & \multirow{2}{*}{0.03} \\
\hline & NBW & $6.57 \pm 3.14$ & 7 & $0-11$ & & \\
\hline \multirow{2}{*}{ Language stimulation } & VLBW & $5.39 \pm 1.12$ & 5 & $2-7$ & \multirow{2}{*}{154.0} & \multirow{2}{*}{0.01} \\
\hline & NBW & $6.17 \pm 0.89$ & 6 & $4-7$ & & \\
\hline \multirow{2}{*}{ Physical environment } & VLBW & $6.09 \pm 1.65$ & 7 & $1-7$ & \multirow{2}{*}{209.0} & \multirow{2}{*}{0.18} \\
\hline & NBW & $5.74 \pm 1.54$ & 6 & $2-7$ & & \\
\hline \multirow{2}{*}{ Responsivity } & VLBW & $3.74 \pm 1.76$ & 4 & $0-6$ & \multirow{2}{*}{256.0} & \multirow{2}{*}{0.85} \\
\hline & NBW & $4.00 \pm 1.13$ & 4 & $0-5$ & & \\
\hline \multirow{2}{*}{ Academical stimulation } & VLBW & $2.78 \pm 2.15$ & 3 & $0-5$ & \multirow{2}{*}{196.5} & \multirow{2}{*}{0.18} \\
\hline & NBW & $3.87 \pm 1.42$ & 4 & $0-5$ & & \\
\hline \multirow{2}{*}{ Modelling } & VLBW & $2.26 \pm 1.29$ & 2 & $0-4$ & \multirow{2}{*}{170.0} & \multirow{2}{*}{0.03} \\
\hline & NBW & $3.09 \pm 1.16$ & 3 & $1-5$ & & \\
\hline \multirow{2}{*}{ Variety } & VLBW & $5.35 \pm 1.23$ & 6 & $2-7$ & \multirow{2}{*}{178.0} & \multirow{2}{*}{0.051} \\
\hline & NBW & $6.39 \pm 1.62$ & 6 & $4-9$ & & \\
\hline \multirow{2}{*}{ Acceptance } & VLBW & $3.65 \pm 0.57$ & 4 & $2-4$ & \multirow{2}{*}{239.0} & \multirow{2}{*}{0.46} \\
\hline & NBW & $3.78 \pm 0.42$ & 4 & $3-4$ & & \\
\hline \multirow{2}{*}{ Total } & VLBW & $33.83 \pm 7.81$ & 31 & $16-45$ & \multirow{2}{*}{161.5} & \multirow{2}{*}{0.02} \\
\hline & NBW & $39.61 \pm 8.75$ & 42 & $20-51$ & & \\
\hline
\end{tabular}

VLBW = very low body weight; NBW = normal body weight. 
Table 3. Descriptive statistics (mean $\pm \mathrm{sd}$, median, and range [min-max] of the motor tests: Movement Assessment Battery for Children (MABC) and Developmental Coordination Disorder Questionnaire (DCDQ), as well as the Cognitive Tests: Weschsler Intelligence Test for Children-III (WISC) and the Swanson, Nolan, and Pelham IV Scale (SNAP IV) for the very low birth weight $(\mathrm{n}=23)$ and the normal body weight $(\mathrm{n}=23)$.

\begin{tabular}{|c|c|c|c|c|c|c|}
\hline Variable & Group & Mean $_{ \pm}$SD & Median & Range (min-max) & Mann Whitney U & $p$ value \\
\hline \multirow{2}{*}{$\mathrm{MABC}^{\star}$ manual dexterity } & VLBW & $3.33 \pm 3.84$ & 1.5 & $0-14$ & \multirow{2}{*}{181.0} & \multirow{2}{*}{0.056} \\
\hline & NBW & $1.46 \pm 2.06$ & 0 & $0-6$ & & \\
\hline \multirow{2}{*}{ MABC* Ball skills } & VLBW & $1.87 \pm 1.66$ & 1 & $0-5$ & \multirow{2}{*}{105.5} & \multirow{2}{*}{$<0.0001$} \\
\hline & NBW & $0.39 \pm 0.89$ & 0 & $0-3$ & & \\
\hline \multirow{2}{*}{ MABC* Balance } & VLBW & $2.98 \pm 3.48$ & 2 & $0-12$ & \multirow{2}{*}{194.0} & \multirow{2}{*}{0.10} \\
\hline & NBW & $1.22 \pm 1.84$ & 0 & $0-6$ & & \\
\hline \multirow{2}{*}{ MABC * Total scores } & VLBW & $8.17 \pm 7.10$ & 7 & $1-29$ & \multirow{2}{*}{125.0} & \multirow{2}{*}{0.002} \\
\hline & NBW & $3.06 \pm 3.80$ & 1.5 & $0-14$ & & \\
\hline \multirow{2}{*}{ DCDQ Total scores } & VLBW & $54.0 \pm 11.3$ & 55 & $33-72$ & \multirow{2}{*}{139.5} & \multirow{2}{*}{0.006} \\
\hline & NBW & $63.0 \pm 7.5$ & 65 & $42-73$ & & \\
\hline \multirow{2}{*}{ WISC-III Cubes } & VLBW & $8.35 \pm 2.15$ & 8 & $6-17$ & \multirow{2}{*}{86.5} & \multirow{2}{*}{$<0.0001$} \\
\hline & NBW & $10.57 \pm 2.25$ & 10 & $7-15$ & & \\
\hline \multirow{2}{*}{ WISC- III Vocabulary } & VLBW & $9.61 \pm 2.62$ & 10 & $5-15$ & \multirow{2}{*}{67.0} & \multirow{2}{*}{$<0.0001$} \\
\hline & NBW & $13.48 \pm 2.45$ & 13 & $10-19$ & & \\
\hline \multirow{2}{*}{ SNAP- IV Attention deficits } & VLBW & $2.04 \pm 2.60$ & 1 & $0-9$ & \multirow{2}{*}{165.5} & \multirow{2}{*}{0.01} \\
\hline & NBW & $0.52 \pm 1.56$ & 0 & $0-7$ & & \\
\hline \multirow{2}{*}{ SNAP- IV Hiperactivity } & VLBW & $2.0 \pm 3.01$ & 0 & $0-9$ & \multirow{2}{*}{215.0} & \multirow{2}{*}{0.20} \\
\hline & NBW & $1.04 \pm 2.16$ & 0 & $0-7$ & & \\
\hline \multirow{2}{*}{ SNAP- IV Total scores } & VLBW & $4.04 \pm 4.95$ & 2 & $0-13$ & \multirow{2}{*}{198.0} & \multirow{2}{*}{0.11} \\
\hline & NBW & $1.57 \pm 3.27$ & 0 & $0-14$ & & \\
\hline
\end{tabular}

VLBW = very low body weight; NBW = normal body weight; *High scores indicate poor performance.

Table 4. Spearman correlation coefficients amongst the Home Observation for Measure of the Environment (HOME), the Movement Assessment Battery for Children (MABC), the Developmental Coordination Disorder Questionnaire (DCDQ), the Weschsler Intelligence Test for Children-III (WISC), and the Swanson, Nolan, and Pelham IV Scale (SNAP IV) total scores and the variables related to birth weight, parents' level of education, and income salary.

\begin{tabular}{|c|c|c|c|c|c|c|c|c|c|}
\hline Variable & $\begin{array}{c}\text { Birth } \\
\text { weight }\end{array}$ & $\begin{array}{l}\text { Mother's } \\
\text { level of } \\
\text { education }\end{array}$ & $\begin{array}{l}\text { Father's } \\
\text { level of } \\
\text { education }\end{array}$ & $\begin{array}{l}\text { Income } \\
\text { salary }\end{array}$ & $\begin{array}{l}\text { HOME- } \\
\text { Total } \\
\text { scores }\end{array}$ & $\begin{array}{l}\text { MABC- } \\
\text { Total } \\
\text { scores }\end{array}$ & $\begin{array}{l}\text { DCDQ- Total } \\
\text { scores }\end{array}$ & $\begin{array}{l}\text { WISC - } \\
\text { Cubes }\end{array}$ & $\begin{array}{c}\text { WISC- } \\
\text { Vocabulary }\end{array}$ \\
\hline Mother's level of education & 0.144 & - & & & & & & & \\
\hline Father's level of education & 0.089 & $0.741^{\star \star}$ & - & & & & & & \\
\hline Income Salary & 0.116 & $0.416^{\star *}$ & $0.431^{\star *}$ & - & & & & & \\
\hline HOME -Total scores & 0.235 & $0.636^{\star *}$ & $0.598^{\star \star}$ & $0.520^{\star \star}$ & - & & & & \\
\hline MABC - Total scores & $-0.547^{\star \star}$ & -0.048 & -0.043 & -0.209 & $-0.308^{\star}$ & - & & & \\
\hline DCDQ - Total scores & $0.437^{* *}$ & 0.165 & $0.301^{*}$ & 0.203 & $0.347^{\star}$ & -0.259 & - & & \\
\hline WISC - Cubes & $0.615^{\star *}$ & $0.410^{* *}$ & $0.355^{*}$ & 0.242 & $0.382^{\star *}$ & $-0.498^{* *}$ & $0.370^{*}$ & - & \\
\hline WISC - Vocabulary & $0.588^{\star *}$ & 0.238 & 0.186 & 0.142 & $0.348^{\star}$ & $-0.292^{*}$ & $0.511^{* *}$ & $0.575^{\star *}$ & - \\
\hline SNAP-IV - Total scores & -0.170 & 0.054 & -0.018 & 0.129 & -0.209 & $0.297^{*}$ & -0.232 & -0.289 & -0.196 \\
\hline
\end{tabular}

${ }^{*} \mathrm{p}<0.05 ;{ }^{* *} \mathrm{p}<0.01$.

The number of children who developed severe sequelae, such as cerebral palsy and sensory deficits $(15.2 \%)$, was higher than that found in the literature. Davis et al. ${ }^{18}$ and Jongmans et al. ${ }^{22}$ found rates of 8.23 and $9.07 \%$, while Mikkola et al. ${ }^{23}$ found a similar rate of $14 \%$, but with preterm children with birth weight $\leq 1,000$ grams. One factor that may have contributed to a higher rate of sequelae in our sample are the conditions of perinatal care, especially considering a small city.

Regarding motor assessment, the children of VLBW group had significantly lower scores on MABC and DCDQ-Brazil tests, suggesting global motor difficulties, consistent with the criteria of motor performance below than that expected for 
the age ${ }^{24}$, necessary for the diagnosis of DCD. The frequency of scores suggestive of DCD identified in the present study (8.7\%) was lower than the ones reported in the literature. Davis et al. ${ }^{18}$, in a similar study, observed a rate of $10 \%$. Other studies observed even higher rates, as Foulder-Hughes and Cooke ${ }^{19}$ and Jongmans et al. ${ }^{22}$ reported rates of $30.7 \%$ and $19 \%$ below the 5 th percentile and $47.8 \%$ and $44 \%$ below the 15 th percentile, respectively. This variability in the findings cannot be attributed to the assessment tools, as in all these studies, the 5th percentile of MABC was adopted as the cutoff point for identification of DCD. However, these studies used different criteria for recruitment of samples, which limits further comparisons.

Although the results of the DCDQ-Brazil and MABC show significant between groups differences, unexpectedly the correlation between these tests was low $(r=-0.259, \mathrm{p}=0.082)$ and not significant, suggesting that the objective data collected with the MABC did not coincide with the observations of parents. Wilson et al. ${ }^{25}$, examining the concurrent validity between the DCDQ and MABC, reported a moderate and significant correlation $(\mathrm{r}=-0.59, \mathrm{p}<0.0001)$, while Schoemaker et al. ${ }^{26}$ reported a significant correlation, but similar to the value observed in the present study $(\mathrm{r}=-0.24, \mathrm{p}=0.001)$. These data support the idea that the two instruments measure different aspects of motor performance, with the DCDQ focusing more on functional skills observed by parents and the MABC on the formal aspects of speed and quality of movements. Although the use of questionnaires is widespread in other countries, in Brazil, they are hardly used and some parents may have had difficulties in the use of scoring criteria, which affects the accuracy of scoring.

As expected, the negative correlation $(r=-0.547, p<0.001)$ between birth weight and results of the MABC, as well as the positive correlation with the DCDQ ( $r=0.437, \mathrm{p}=0.002)$, indicated that children born with lower weight and lower gestational age were those that showed worse motor performance, which demonstrates the high influence of biological factors in motor development in the first years of life. It should be emphasized that even with the exclusion of children with severe sequelae, these correlations persist at least until the beginning of schooling, which emphasizes the insidious character of prematurity.

Environmental factors seem to play an important role in the cognitive development ${ }^{27}$, but the findings in relation to the environmental influence on motor aspects are scarse and inconsistent. Goyen and $\mathrm{Lui}^{20}$ examined the influence of home environment in the development of motor skills, and the results showed that children aged 18 months and 5 years, with lower scores on the HOME, consistently had worse performance in gross motor skills. Chen, Jeng and $\mathrm{Tsou}^{28}$, on the other hand, considered that sociodemographic factors, therefore environmental, are more associated with fine motor performance. In the present study, the correlations between the HOME and all the motor tests were weak, but statistically significant, suggesting that the quality of home environment has some influence on motor development. Another interesting point of this study is that both the education of parents and the income salary had moderate correlation with results of the HOME, which possibly resulted in greater availability of resources to purchase of toys and educational materials, with the provision of a more stimulating home environment.

In cognitive tests, children in the VLBW group had worse performance than the children in NBW group, but in both subtests of WISC-III, mean performance was within normal limits for age. These results confirm findings from other authors who found a level of intelligence within normal limits in different samples of preterm children and with low birth weight ${ }^{19,29}$. Méio, Lopes and Morsch ${ }^{17}$, on the other hand, checking the cognitive development of children with birth weight $\leq 1,500$ grams at preschool age, found that the mean Intelligence Quotient of these children were below the normal range. While Martins et al. ${ }^{29}$ found no cognitive differences between children born preterm and with low birth weight with full-term children aged 6 years. Because of the complexity of the factors involved and the impact of cognitive development in various aspects of children's lives, this is an area that merits further research.

Considering the quality of home environment, significant differences between groups were found, with better results for the NBW group in the HOME total score and in the subscales learning material, language stimulation and modeling. Despite the differences in other areas of the HOME were not significant, the VLBW group scored lower in all areas, except in the physical environment. Thus, paradoxically, the results point to a less stimulating environment for the VLBW group, in which the biological risks to development are already pronounced. Children exposed to both risk factors are more likely to have developmental disorders; furthermore, children with biological risks may be more vulnerable to the influence of unfavorable environments if compared to full-term children with $\mathrm{NBW}^{9}$.

With regards to behavior, the results of the SNAP-IV showed a significant between-group difference, with signs of poorer attention and worse results for the VLBW group. McGrath et al. ${ }^{30}$ documented a significant increase, around four times more, of the prevalence of ADHD in children born preterm and with low birth weight, compared to their peers with NBW. Hemgren and Persson ${ }^{21}$ and Seitz et al. ${ }^{1}$ investigated the correlation between motor performance, attention deficits and cognitive functions in children with low birth weight, and in both studies, children with low birth weight 
showed deficits in attention and coordination, associated with perceptual-motor delays important for the development of academic skills. Although age and the instruments used in the present study did not permit precise identification, the results point to greater difficulty in attention in VLBW group, which may be predictive of future diagnosis of $\mathrm{ADHD}$ at school age.

This study has limitations, since the sample was severely reduced due to the high mortality rate and losses due to changes of address. It is noteworthy; however, that it was possible to locate $71.74 \%$ of the surviving children, and the difference between groups was evident, even with the relatively small sample. The data are consistent with the literature, but it is important to invest in multicenter studies, as a strategy to obtain larger samples that allow a better characterization of the impact of prematurity among Brazilian children. Another limitation was that, due to the lack of standardized instruments for Brazilian children, it was necessary to use imported tests. However, comparisons were made only with the control group of Brazilian children, tested under the same conditions, without the use of normative data.
The present study contributes to support the evidence that children born preterm and with low birth weight are more likely to have motor and cognitive difficulties than their peers born full-term and with NBW. Environmental factors seem to contribute negatively to enhance the biological risks in the development outcome of these children. As most of them show apparently normal development, their difficulties are often more evident only at school age, when motor and cognitive demands are greater. The results of this study indicate the importance of public policies of post-natal assistance and implementation of longitudinal development follow up services, to follow these children until school age.

\section{Acknowledgements : :}

To the children, parents and teachers who participated in the study and to the Conselho Nacional de Desenvolvimento Científico e Tecnológico (CNPq) and Fundação de Amparo à Pesquisa do Estado de Minas Gerais (FAPEMIG) for funding this study.

\section{References: : :}

1. Seitz J, Jenni OG, Molinari L, Caflish J. Largo RH, Latal Hajnal B. Correlations between motor performance and cognitive functions in children born $<1250 \mathrm{~g}$ at school age. Neuropediatrics. 2006;37(1):6-12.

2. Garbarino J, Ganzel B. The human ecology of early risk. In: Shonkoff JP, Meisels SJ (Eds). Handbook of early childhood intervention. $2^{\text {nd }}$ ed. New York: Cambridge University Press; 2000. p. 76-93.

3. Holditch-Davis D, Bartlett TR, Belyea M. Developmental problems and interactions between mothers and prematurely born children. J Pediatr Nursing. 2000;15(3):157-67.

4. Espírito Santo JL, Portuguez MW, Nunes ML. Cognitive and behavioral status of low birth weight preterm children raised in a developing country at preschool age. J Pediatr (Rio J). 2009:85(1):35-41

5. Linhares MBM, Chimello JT, Bordin MBM, Carvalho AEV, Martinez FE. Desenvolvimento psicológico na fase escolar de crianças nascidas pré-termo em comparação com crianças nascidas a termo. Psicol Reflex Crít. 2005;18(1):109-17

6. Magalhães LC, Catarina PW, Barbosa VM, Mancini MC, Paixão ML. Estudo comparativo sobre 0 desempenho perceptual e motor na idade escolar em crianças nascidas pré-termo e a termo. Arq Neuropsiquiatr. 2003;61(2A):250-5.

7. Bordin MBM, Linhares MBM, Jorge SM. Aspectos cognitivos e comportamentais na média meninice de crianças nascidas pré-termo e com muito baixo peso. Psicol Teor Pesqui. 2001;17(1):49-57

8. Carvalho AEV, Linhares MBM, Martinez FE. História de desenvolvimento e comportamento de crianças nascidas pré-termo e baixo peso (<1.500g). Psicol Reflex Crít. 2001;14(1):1-33.

9. Mancini MC, Megale L, Brandão MB, Melo APP, Sampaio RF. Efeito moderador do risco social na relação entre risco biológico e desempenho funcional infantil. Rev Bras Saúde Matern Infant. 2004:4(1):25-34.

10. Prado MS. Tradução e adaptação cultural do Developmental Coordianation Disorder Questionnaire (DCDQ) [dissertação]. Belo Horizonte, MG: UFMG; 2007.

11. Henderson SE, Sudgen DA. Movement assessment battery for children. New York: Psychological Corporation/Harcourt Brace-Jovanovich; 1992.
12. Fiqueiredo VLM. WISC III - Escala de Inteligência para Crianças. São Paulo: Casa do Psicólogo; 2002.

13. Satler JM. Assessment of children. The WPPSI - R and WISC III Suplement. $3^{\text {a }}$ ed. San Diego; 1992

14. Swanson J, Lerner M, March J, Gresham FM. Assessment and intervention for attention-deficit/ hyperactivity disorder in the schools. Lessons from the MTA study. Pediatr Clin North Am. 1999;46(5):993-1009.

15. Mattos P, Serra Pinheiro MA, Rohde LA, Pinto D. Apresentação de uma versão em português para uso no Brasil do instrumento MTA-SNAP IV de avaliação de sintomas de transtorno do déficit de atenção/hiperatividade e sintomas de transtorno desafiador e de oposição. Rev Psiquiatr Rio Gd. Sul. 2006;28(3):290-7.

16. Caldwell BM, Bradley RH. Home inventory administration manual. Arkansas: Print Design, Inc; 2003.

17. Méio MDBB, Lopes CS, Morsch DS. Fatores prognósticos para o desenvolvimento cognitivo de prematuros de muito baixo peso. Rev Saúde Pública. 2003;37(3):311-8.

18. Davis NM, Ford GW, Anderson PJ, Doyle LW; Victorian Infant Collaborative Study Group Developmental coordination disorder at 8 years of age in a regional cohort of extremely-lowbirthweight or very preterm infants. Dev Med Child Neurol. 2007;49(5): 325-30.

19. Foulder-Hughes $\mathrm{L}$, Cooke RWI. Do mainstream schoolchildren who were born preterm have motor problems? British Journal of Occupational Therapy. 2003;66(1):9-16.

20. Goyen TA, Lui K. Longitudinal motor development of "apparently normal" high-risk infants at 18 months, 3 and 5 years. Early Hum Dev. 2002;70(1-2):103-15.

21. Hemgren E, Persson K. Associations of motor co-ordination and attention with motor-perceptual development in 3-year-old preterm and full-term children who needed neonatal intensive care. Child Care Health Dev. 2003;33(1):11-21.

22. Jongmans MJ, Mercuri E, Dubowitz LMS, Henderson SE. Perceptual-motor difficulties and their concomitants in six-year-old children born prematurely. Hum Mov Sci. 1998;17(4):629-53.

23. Mikkola K, Ritari N, Tommiska V, Salokorpi T, Lehtonen L, Tammela 0, et al. Neurodevelopmental outcome at 5 years of age of a national cohort of extremely low birth weight infants who were born 
in 1996-1997. Pediatrics. 2005;116(6):1391-400.

24. American Psychiatric Association, APA. Manual diagnóstico e estatístico de transtornos mentais: DSM-IV. TR. $4^{\mathrm{a}}$ ed. Porto Alegre: Artmed; 2002.

25. Wilson BN, Kaplan BJ, Crawford SG, Campbell A, Dewey D. Reliability and validity of a parent questionnaire on childhood motor skills. Am J Occup Ther. 2000;54(5):484-93.

26. Schoemaker MM, Flapper B, Verheij NP, Wilson BN, Reinders-Messelink HA, de Kloet A. Evaluation of the Developmental Coordination Disorder Questionnaire as a screening instrument. Dev Med Child Neurol. 2006;48(8):668-73.

27. Andrade SA, Santos DN, Bastos AC, Pedromônico MRM, Almeida-Filho NA, Barreto ML.
Ambiente familiar e desenvolvimento cognitivo infantil: uma abordagem epidemiológica. Rev Saúde Pública. 2005;39(4):606-11.

28. Chen PS, Jeng SF, Tsou KI. Developmental function of very-low-birth weight infants and full-term infants in early childhood. J Formos Med Assoc. 2004;103(1):23-31.

29. Martins IMB, Linhares MBM, Martinez FE. Indicadores de desenvolvimento na fase pré-escolar de crianças nascidas pré-termo. Psicol Estud. 2005;10(2):235-43.

30. McGrath MM, Sullivan M, Devin J, Fontes-Murphy M, Barcelos S, DePalma JL, et al. Early precursors of low attention and hyperactivity in a preterm sample at age four. Issues Compr Pediatr Nurs. 2005;28(1):1-15. 